\title{
MODEL PEMBANGUNAN HUTAN DESA DI KELURAHAN LATUPPA KECAMATAN MUNGKAJANG KOTA PALOPO
}

\section{(Model Of Village Forest Development In Latuppa, Mungkajang District Palopo City)}

\author{
Irawati $^{1}$, Yusran Jusuf ${ }^{2}$, Muhammad Dassir ${ }^{2}$ \\ ${ }^{1} \mathrm{KPH}$ Latimojong Dishut sulsel \\ ${ }^{2}$ Dosen Jurusan Kehutanan Fakultas Kehutanan Universitas Hasanuddin Makassar \\ Email : irawatidjalal@ymail.com
}

\begin{abstract}
Community activities in the forest areas such as illegal logging and conversion of forests to plantations have caused deforestation. Therefore, sustainable community forest management is needed. The aim of the study was to find out the form of forest use by the community around the prospective village forest location and formulate a model of village forest development in Palopo City. The research method used through interviews using questionnaires and field surveys. Data analysis was conducted in qualitative and quantitative descriptive. The results show that there are two types of forest utilization by the community, namely gardening and the use of non-timber forest products. Plants that are cultivated in the garden are cocoa, cloves, fruits, and forest plants. Whereas the non-timber forest products that have been utilized by the community are palm sugar, bamboo, bee cultivation, nutmeg, candlenut and fruits and environmental services using clean water. Untapped non-timber forest products, namely rattan, and considerable tourism potential. The use of rattan has not been done because the community does not yet have a utilization permit. The village development model that is suitable for the Siguntu Protection Forest is the maximum utilization of non-timber forest products and the use of damaged land by planting MPTs such as nutmeg and candlenut and the use of waterfalls as natural tourism potential.
\end{abstract}

Keywords : community forest management,deforestationnon-timber forest products, Palopo city.

\begin{abstract}
Abstrak
Aktivitas masyarakat dalam kawasan hutan seperti penebangan liar dan alih fungsi hutan menjadi perkebunan mengakibatkan kerusakan hutan. Oleh karena itu diperlukan pengelolaan hutan oleh masyarakat secara lestari. Tujuan dari penelitianyaitu untuk mengetahui bentuk pemanfaatan hutan oleh masyarakat sekitar calon lokasi hutan desa dan merumuskan model pembangunan hutan desa di Kota Palopo. Metode penelitian yang digunakan melalui wawancara dengan menggunakan kuesioner dan survei lapangan. Analisis data dilakukan secara deskriptif kualitatif dan kuantitatif. Hasil menunjukkan bahwa ada dua macam pemanfaatan hutan oleh masyarakat yaituberkebun dan pemanfaatan hasil hutan bukan kayu. Tanaman yang dibudidayakan di lahan kebun yaitu kakao,cengkeh, buah-buahan dan tanaman kehutanan. Sedangkan Hasil hutan bukan kayu yang telah dimanfaatkan oleh Masyarakat yaitu nira aren, bambu, budidaya lebah, pala, kemiri dan buah-buahan serta jasa lingkungan pemanfaatan air bersih. Hasil hutan bukan kayu yang belum dimanfaatkan yaitu rotan dan potensi wisata yang cukup besar. Pemanfaatan rotan belum dilakukan karena masyarakat belum memiliki izin pemanfaatan. Model pembangunan
\end{abstract}


desa yang cocok untuk Hutan Lindung Siguntu yaitu pemanfaatan secara maksimal hasil hutan bukan kayu dan pemanfaatan lahan yang rusak dengan penanaman tanaman MPTs seperti pala dan kemiri serta pemanfaatan air terjun sebagai potensiwisata alam.

Kata Kunci : hasil hutan bukan kayu, kerusakan hutan, kota palopo, pengelolaan hutan desa

\section{PENDAHULUAN}

Saat ini masyarakat di sekitar lokasi hutan mengelola lahan secara turun temurun di dalam kawasan hutan lindung. Mereka telah mengembangkan tanaman budidaya sebagai sumber matapencaharian mereka. Pemanfaatan dan penggunaan hutan oleh masyarakat umumnya masih tergolong kegiatan yang bersifat illegal dan cenderung merusak hutan. Sebagian warga masyarakat cenderung mengkonversi lahan hutan menjadi lahan usaha perkebunan/komoditi pangan, belum mengusahakan komoditi kehutanan (Alam 2011).

Pengelolaan hutan secara lestari sangat diperlukan untuk mempertahankan fungsi pokok hutan. Menurut Soedirman (1995), hutan lestari adalah proses pengelolaan areal hutan permanen untuk mencapai satu atau lebih tujuan yang telah ditentukan, dengan berdasarkan kontinuitas produksi dan manfaat lain yang diinginkan, tanpa mengakibatkan kemunduran nilai produktivitas hutan di masa datang dan timbulnya akibat yang diharapkan pada komponen fisik dan lingkungan sosialnya. Dalam konsep pengelolaan hutan berbasis masyarakat yang dimuat melalui Kehutanan masyarakat (community forestry) (Soedirman 1995).

Alam (2011), menjelaskan bahwa pengelolaan hutan yang menempatkan masyarakat sekitar hutan sebagai pelaku utama dalam mengelola sumberdaya hutan untuk meningkatkan kesejahteraan mereka dan melestarikan fungsi hutan. Sejalan dengan Suwarno (2011), yang menyatakan bahwa pengelolaan hutan berbasis masyarakat (PHBM) merupakan alternatif pengembangan pengelolaan hutan ke depan. Sehingga pemberian hak kepada masyarakat dan menempatkan masyarakat sebagai pelaku utama pembangunan dan pengelolaan hutan harus dilakukan karenasesuai dengan amanah Undang -Undang Republik Indonesia No 41 Tahun 1999 Tentang Kehutanan, khususnya pada penjelasan pasal 5 dimana "hutan desa adalah hutan negara yang dimanfaatkan oleh desa untuk kesejahteraan masyarakat". Kemudian Peraturan Pemerintah No 6 tahun 2007 Tentang Tata Hutan dan Penyusunan Rencana

Pengelolaan Hutan serta Pemanfaatan Hutan, hutan desa didefinisikan sebagai hutan negara yang belum dibebani izin atau hak yang dikelola oleh desa untuk kesejahteraan masyarakat desa sedangkan dalam Peraturan Menteri Kehutanan Nomor : P.49/MenhutII/2008 Tentang Hutan Desa. "Hutan desa adalah hutan negara yang dikelola oleh desa dan dimanfaatkan untuk kesejahteraan desa serta tidak dibebani izin/hak". Hutan Desa menurut Supratman dan Sahide (2010), adalah kebutuhan masyarakat untuk mendapatkan hak pengelolaan kawasan hutan secara legal, mengelola kawasan hutan secara terencana dan berkelanjutan, serta mendapatkan manfaat yang lebih besar untuk kesejahteraan rumah tangga petani dan kesejahteraan desa. Dari beberapa pengertian ini pemerintah memberikan peluang kepada masyarakat untuk ikut dalam mengelola kawasan hutan, dalam arti bahwa pemerintah mengakomodasi kepentingan dan partisipasi masyarakat secara luas di dalam pengelolaan hutan. Partisipasi masyarakat dalam pengelolaan kawasan hutan diharapkan mampu meningkatkan kesejahteraan. 
Palopo merupakan salah satu daerah otonom di Propinsi Sulawesi Selatan yang bersatus kota, akan tetapi mata pencaharian penduduk di sebelah selatan, barat dan utara Kota Palopo sebagian besar adalah bertani, dan bahkan masih banyak yang tergantung hidupnya pada hutan. Kelurahan Latuppa merupakan salah satu kelurahan dari 4 kelurahan di Kecamatan Mungkajang Kota Palopo yang memiliki kawasan hutan lindung dengan luas $\pm 653 \mathrm{Ha}$, dengan ketinggian 500 $m$ dpl. Kawasan Hutan Lindung Latuppa memiliki potensi hasil hutan bukan kayu (HHBK). Selain itu juga terdapat air terjun sebagai sumber mata air PDAM kota Palopo dan kaya akan keanekaragaman hayati (biodiversitas).

Beberapa penelitian yang pernah dilakukan diantaranya Mas'ud et al. (2011), dengan judul Model Pembangunan Hutan Tanaman Rakyat Pola Mandiri Di Desa BacuBacu Kabupaten Barru. Penelitian Sumantera. dan Peneng (2005), Pemberdayaan Hutan bamboo sebagai penunjang sosial ekonomi masyarakat Desa Pakraman Angseri, tabanan, Bali. Dan penelitian Ristianasari et al. (2013), dengan judul Dampak Program Pemberdayaan Model Desa Konservasi Terhadap Kemandirian Masyarakat: Kasus Di Taman Nasional Bukit Barisan Selatan Lampung. Penelitian-penelitian di atas masih terfokus pada masyarakat sebagai pelaku utama dalam mengelola sumber daya hutan untuk menjaga kelestarian fungsi hutan.

Pengelolan hutan yang telah dilakukan olehmasyarakat jika dibiarkan tanpa ada aturan-aturan yang mengikat ditingkat masyarakat, maka kemungkinan besar kerusakan kawasan hutan lindung akan semakin besar, dan impasnya akan menenggelamkan Kota Palopo. Untuk itu, penelitian ini bertujuanuntuk mengetahui bentuk pemanfaatan hutan oleh masyarakat sekitar calon lokasi hutan desa dan merumuskan model pembangunan hutan desa di Kota Palopo

\section{METODE PENELITIAN}

Penelitian ini dilaksanakan dari bulan Maret sampai April 2015. Pengambilan data awal berupa data sekunder dilakukan melalui penelusuran literatur yang dimulai sejak Bulan Desember 2014, sedangkan pengambilan data lapangan dilaksanakan pada Bulan Maret sampai April 2015. Pemilihan lokasi dilakukan secara purposive, yaitu penentuan lokasi secara sengaja dengan alasan bahwa lokasi merupakan calon hutan desa yang saat ini dalam proses perizinan, dimana tepatnya berada di Kelurahan Latuppa Kecamatan Mungkajang Kota Palopo.

Jenis data yang diperlukan meliputi data primer yang diperoleh melalui wawancara menggunakan kuesioner dan survey lapangan: (1) potensi biofisik (letak dan luas wilayah, HHBK), (2) potensi wisata, (3) kondisi sosial ekonomi. Data sekunder diambil untuk melengkapi dan menunjang data primer. Data tersebut diperoleh dari Dinas Kehutanan dan Perkebunan Kota Palopo, Kantor Lurah Latuppa, dan atau literature-literatur yang relevan dengan penelitian ini. Analisis data dengan menganalisis potensi biofisik kawasan hutan secara deskriptif kualitatif dan analisis pendapatan masyarakat didalam dan sekitar hutan secara kuantitatif yang disajikan secara deskriptif.

\section{HASIL DAN PEMBAHASAN}

\section{Gambaran Umum Hutan Desa Latuppa}

Hutan Lindung Latuppa sebagian wilayahnya akan diusulkan menjadi areal kerja hutan desa seluas 112 hektar yang terletak di Kelurahah Latuppa, tepatnya di daerah Siguntu. Secara geografis, areal kerja 
hutan desa tersebut berada di sebelah utara dari Barat Kelurahan Latuppa, yang terletak diusulkan merupakan batas terjauh dari lokasi yang telah dimanfaatkan oleh masyarakat yaitu \pm 30 hektar dari total 112 hektar. Calon lokasi hutan desa ini berada di daerah hulu DAS Latuppa dan hilirnya berada di Kota Palopo, sehingga kerusakan yang terjadi di daerah ini akan mempengaruhi Kota Palopo. Dari luasan ini hampir semuanya sudah dimanfaatkan oleh masyarakat baik sebagai kebun atau pun hanya untuk pemanfaatan hasil hutan bukan kayu. Pemanfaatan masyarakat sekitarnya terhadap hutan lindung ini belum bisa memenuhi kebutuhan hidupnya, terbukti dengan keluarnya kaum laki-laki ke daerah lain untuk mencari pekerjaan sambilan.

\section{Potensi Hasil Hutan Bukan kayu}

Potensi hasil hutan bukan kayu (HHBK) yang ada di areal calon hutan desa cukup banyak dan berpotensi untuk dikembangkan, pengelolaan HHBK ini cukup sederhana, seperti pengelolaan gula aren. Berdasarkan hasil wawancara dengan masyarakat, selain aren juga ada rotan, bamboo,dan buah-buahan. HHBK ini telah banyak dimanfaatkan masyarakat dan bahkan sudah menjadi mata pencaharian beberapa orang penduduk.

\section{Potensi Wisata}

Wisata adalah salah satu kebutuhan manusia, dengan berwisata maka dapat menghilangkan kepenatan berfikir. Akhir pekan, biasanya orang - orang akan berwisata, dan khusus untuk Kota Palopo, salah satu tempat tujuan wisata adalah Latuppa. Potensi wisata Latuppa adalah aliran air sungai yang belum tercemar, panorama alam yang begitu indah serta keindahan air terjunnya. Ada beberapa air terjun yang ada di Latuppa, sebagian telah dijadikan tempat wisata dan sebagian lagi belum diketahui masyarakat pada $120^{\circ} 6$ '24,08' LU dan $3^{\circ} 2^{\prime} 10,42^{\prime \prime}$ BT. Batas -batas terluar dari lokasi yang akan umum, karena lokasinya yang sulit untuk dijangkau.

Air terjun memiliki manfaat yang cukup banyak bagi kehidupan manusia, diantaranya sebagai tempat rekreasi. Air terjun terjadi dengan sendirinya tanpa rekayasa manusia, hal ini terjadi secara alami. sebagai tempat rekreasi karena keindahannya. Manfaat yang lain dapat digunakan sebagai sumber energi potensial yang dapat digunakan sebagai pembangkit tenaga listrik. Tinggi air terjun yang dimaksud diatas adalah kurang lebih 25 meter. Air ini mengalir dari atas kebawah dengan menuruni beberapa tingkatan batu yang bersusun, sehingga air terjun ini nampak indah. Air terjun ini berada di dalam kawasan hutan lindung sehingga jarang di kunjungi dan jika kita berjalan kaki dari batas hutan lindung maka kita dapat menempuhnya dengan waktu kurang lebih 2.5 jam.

Penelitian ini menunjukkan ada dua bentuk pemanfaatan kawasan hutan yang dilakukan masyarakat yaitu berkebun dan pemanfaatan hasil hutan bukan kayu. Kawasan hutan yang dijadikan kebun telah ditanami tanaman perkebunan dan kehutanan yaitu kakao, cengkeh, buah-buahan dan tanaman pala. Model pembangunan Hutan Desa Latuppa dibagi atas 3 yaitu, kelola kawasan, kelola usaha dan kelola kelembagaan. Kelola kawasan yang perlu dilakukan dalam pembangunan Hutan Desa Latuppa meliputi penataan lahan, perlindungan dan pengawasan areal.Penataan lahan disesuaikan dengan sebaran potensi hasil hutan bukan kayu yang ada di dalam Hutan Lindung. Pengelolaan kawasan berdasarkan sebaran potensi dilakukan, karena ditinjau dari segi ekologi, tidak akan merusak lingkungan atau apa yang telah ada di dalam hutan (habitat asli), bahkan bisa menambah kwantitas dari potensi tersebut.

Kelola kawasan ini dapat disesuaikan dengan draft rencana pengelolaan hutan desa, 
yaitu untuk penataan lokasi lahan garapan ditentukan bersama-sama antar petani penggarap, kelompok, pemerintah desa dan dinas terkait serta pihak - pihak yang berkepentingan. Batas lahan, batas antar petani penggarap, serta batas antar desa diperjelas. Kemudian untuk batas garapan ditentukan secara bersama-sama antara petani penggarap, Kelompok tani hutan, pemerintah desa, dinas terkait dan pihak-pihak yang berkepentingan. Hal ini dilakukan agar tidak terjadi kesalapahaman atau sengketa antar petani penggarap

Luas lahan garapan ditentukan secara bersama-sama antara petani penggarap, Kelompok, Pemerintah Desa, Dinas terkait dan pihak-pihak yang berkepentingan. Luas lahan garapan ini disesuaikan dengan kemampuan petani penggarap. Kemudian inventarisasi potensi sumber daya hutan/kawasan dilakukan bersama - sama antara petani penggarap, kelompok, Pemerintah Desa, Dinas terkait dan pihak yang berkepentingan, agar memudahkan dalam pengawasan.Lahan yang diterlantarkan oleh petani penggarap, statusnya akan diperjelas pada saat penataan lahan. Akan tetapi Status tanah tetap milik negara dan tidak boleh diperjualbelikan. Luas lahan garapan maksimal 2 hektar. Hal ini dipertegas karena status petani adalah penggarap, dan lahan yang dikelola tetap adalah milik negara, tetapi lembaga pengelola dalam hal ini Bumdes menjadi pemegang izin pengelolaan hutan desa.

Kemudian untuk perlindungan dan pengawasan areal hutan desa, mempertimbangkan wilayah sebagai hutan lindung sehingga lahan 200m sekeliling mata air tidak boleh ditanami tanaman pokok (misalnya tanaman kayu apa). Lahan sekeliling mata air akan dijadikan areal penyangga mata air dengan cara ditanami tanaman masyarakat yang tidak untuk ditebang. Kemudian lahan 100m kanan kiri sungai tidak boleh ditanami tanaman pokok. Lahan ini akan dijadikan areal penyangga DAS (daerah aliran sungai) dengan cara ditanami tanaman masyarakat yang tidak untuk ditebang. Selain itu lahan dengan kemiringan $>30^{\circ}$ tidak boleh ditanami tanaman pokok, lahan tersebut akan dijadikan kawasan lindung dengan cara ditanami tanaman masyarakat yang tidak untuk ditebang. Ketentuan ini sesuai dengan Peraturan Menteri Kehutanan Nomor :P.89/Menhut-II/2014 tentang Hutan Desa pasal 19 ayat (4) yaitu "Kawasan perlindungan sebagaimana dimaksud pada ayat (2) huruf a, memiliki kriteria : a. memiliki potensi kayu pada hutan alam pada hutan produksi; b. berfungsi sebagai perlindungan tata air, (catchment area, kanan kiri sungai, sumber mata air; b. memiliki kelerengan $>30 \%$; c. sebagai perlindungan flora dan fauna; dan d. memiliki nilai sosial budaya". Selain itu, pengamanan hutan diserahkan kepada petani penggarap dilahan garapannya, yang bekerjasama dengan petani penggarap batas lahan masing-masing. Larangan pengambilan kayu karena masuk pada hutan lindung, sehingga pihak pemegang izin pemanfaatan hutan desa/ lembaga pengelola hutan desa memberikan aturan bahwa jika terjadi pengambilan kayu atau pencurian kayu di lahan garapannya maka harus melaporkan kepada pihak lembaga pengelola hutan desa.

Kelola usaha hasil hutan bukan kayu yang telah dimanfaatkan sampai saat ini masih bertahan dan menjadi mata pencaharian penduduk sekitar Hutan Lindung Latuppa adalah pemanfaatan nira aren untuk dijadikan gula merah. Namun pembuatan gula merah ini dalam 1 pohon hanya bisa dipanen selama 4 sampai 5 bulan. Sehingga produksi gula merah tidak kontinyu, karena harus menunggu atau melihat pohon yang lain yang siap untuk dipanen.Mata pencaharian ini sebenarnya sudah menjadi usaha industri 
kecil. Pengolahan gula aren yang dilakukan oleh masyarakat setempat masih menggunakan peralatan yang sederhana dan usaha ini berkembang hingga sekarang. Disamping itu penggunaan gula aren sebagai bahan baku industri pangan sehari-hari banyak dipakai oleh berbagai lapisan masyarakat, baik di kota maupun di desa. Hal ini tentunya memberikan peluang untuk mengembangkan industri pengolahan gula aren secara lebih meluas.

Pengolahan gula aren yang dilakukan oleh masyarakat latuppa dengan bahan bakunya berasal dari pemanfaatan tanaman aren belum dibudidayakan secara intensif. Hal ini tentunya merupakan permasalahan, karena pada akhirnya akan menimbulkan kekurangan bahan baku yang mengakibatkan produk akan terbatas. Minimnya modal yang dimiliki, juga merupakan salah satu persoalan bagaimana memenuhi permintaan pasar. karena modal ini mempunyai peranan yang penting dalam menentukan maju mundurnya suatu usaha. Kebanyakan industri kecil tidak mampu berkembang atau bersaing karena sering terbentur masalah modal, sehingga sering mengalami defisit dalam produksi.

Selain aren, bambu juga merupakan HHBK yang dimanfaatkan masyarakat, tetapi hanya sekedar untuk kebutuhan masyarakat, belum dijadikan sebagai produk yang bisa bernilai ekonomi. Masyarakat belum memiliki keterampilan dalam memanfaatkan bambu, selain itu juga karena persolan modal. Pemanenan bambu dilakukan pada saat masyarakat membutuhkannya seperti jika ada acara atau pesta. Bambu dipakai sebagai tiang dan lantai pada rumah panggung dan bahkan dijadikan dinding. Cara pemanenan ini dilakukan masyarakat di latuppa, sehingga kualitas bambu tidak terjamin. Hal tersebut dilakukan karena bambu hanya untuk konsumsi sendiri bukan untuk dikomersialkan. Sehingga hal yang harus dilakukan adalah bagaimana meningkatkan keterampilan masyarakat .
Usaha lain yang bisa dikembangkan juga di Latuppa adalah usaha kerajinan rotan. Rotan sebagaimana telah ditampilkan sebelumnya memiliki manfaat yang banyak misalnya kerajinan rotan. Jika hal ini dikembangkan, maka bisa menjadi sumber penerimaan masyarakat.Bahan baku kerajinan rotan masih banyak dijumpai di dalam lokasi hutan desa, akan tetapi rotan ini belum dimanfaatkan karena selain izin pemanfaatan belum ada, juga karena keterampilan petani masih rendah. Di daerah lain, kerajinan rotan menjadi sumber penerimaan utama keluarga seperti di daerah cirebon hampir semua masyarakat memiliki industri rumah tangga berupa kerajinan rotan, sehingga Kota Cirebon dikenal dengan industri kerajinan rotannya.

Lebah madu juga salah satu usaha yang saat ini telah dibudidayakan masyarakat adalah jenis Avis trigona, lebah ini didapatkan dari peternak-peternak lebah, dipanen jika sudah berumur 4 bulan didalam box, karena koloni sudah dewasa dan memiliki ratu. Pada saat diambil dari peternak lebah. Dalam 1 box bisa didapatkan 1 botol madu dan dijual dengan harga Rp 100.000. Budidaya lebah ini tidak terlalu sulit, karena pakan banyak tersedia di alam, mengingat Latuppa adalah daerah yang berbatasan langsung dengan hutan.

Selanjutnya adalah kelola kelembagaan saat ini di Siguntu, yaitu lokasi yang berbatasan langsung dengan calon hutan desa memiliki 1 kelompok tani yang masih aktif, yaitu Kelompok Tani Sepon. Kelompok ini memiliki anggota sebanyak 25 orang termasuk para pengurusnya. Setiap bulan kelompok ini melakukan pertemuan rutin, yaitu setiap hari jumat minggu pertama. Setiap pertemuan anggota kelompok tani memberikan sumbangan sebagai kas kelompok. Namun iuran ini tidak berjalan sesuai dengan kesepakatan, karena jumlah anggota yang menghadiri pertemuan kurang dari setengah anggota kelompok, sehingga aturan-aturan yang telah disepakati tidak 
berjalan. Ketidakhadiran anggota disebabkan karena umumnya penduduk yang ada di siguntu pada waktu-waktu tertentu bekerja sebagai buruh bangunan dan buruh tani diluar daerah.

\section{KESIMPULAN DAN SARAN}

Hasil peneltian menunjukan bahwa bentuk pemanfaatan hutan oleh masyarakat ada 2 yaitu berkebun dan pemanfaatan hasil hutan bukan kayu. Tanaman yang dibudidayakan di lahan kebun yaitu kakao, cengkeh, buah-buahan dan tanaman kehutanan. Kemudian untuk hasil hutan bukan kayu yang telah dimanfaatkan oleh Masyarakat yaitu nira aren, bambu, budidaya lebah, pala, kemiri dan buah-buahan serta jasa lingkungan yaitu pemanfaatan air bersih. HHBK lain yang belum dimanfaatkan yaitu rotan dan potensi wisata yang cukup besar. Pemanfaatan rotan belum dilakukan karena masyarakat belum memiliki izin pemanfaatan. Model pembangunan hutan desa yang cocok untuk Hutan Lindung Siguntu yaitu pemanfaatan secara maksimal hasil hutan bukan kayu dan pemanfaatan lahan yang rusak dengan penanaman tanaman MPTs seperti pala dan kemiri serta pemanfataan air terjun sebagai potensi wisata alam.

Pembinaan teknis yang lebih intensif kepada masyarakat tentang bagaimana memanfaatkan hasil hutan bukan kayu secara maksimal tanpa merusak hutan dan perlunya kebijakan pemerintah daerah untuk pemanfaatan hutan lindung sebagai hutan desa dalam mengurangi persoalan konflik lahan, illegal logging dan banjir.

\section{DAFTAR PUSTAKA}

Alam Syamsu. 2011. Pelestarian Hutan dan Pengentasan Kemiskinan Melalui Pengembangan Kehutanan Masyarakat (Suatu Tinjauan Ekonomi Kehutanan).
Pidato Penerimaan Jabatan Guru Besar Tetap dalam Ilmu Kehutanan Universitas Hasanuddin. Makasar.

Kementrian Kehutanan. 1999. UndangUndang No. 41 Tentang Kehutanan. Jakarta. Indonesia.

Kementrian Kehutanan. 2007. Peraturan Pemerintah No 6 Tentang Tata Hutan Dan Penyusunan Rencana Pengelolaan Hutan Serta Pemanfaatan Hutan. Jakarta. Indonesia

Kementrian Kehutanan. 2008. Peraturan menteri kehutanan No. 49 Tentang Hutan Desa. Jakarta. Indonesia.

Mas'ud Emban Ibnurusyd., Supratman., dan Malamassam Daud. 2011. Model Pembangunan Hutan Tanaman Rakyat Pola Mandiri Di Desa Bacu-Bacu Kabupaten Barru. Jurnal Hutan dan Masyarakat. Volome. 6, No.2.

Ristianasari., Muljono Pudji., \& Gani Darwis S. 2013. Dampak Program Pemberdayaan Model Desa Konservasi Terhadap Kemandirian Masyarakat: Kasus Di Taman Nasional Bukit Barisan Selatan Lampung. JURNAL Penelitian Sosial dan Ekonomi Kehutanan Vol. 10 No. 3 September 2013, Hal. 173 - 185

Soedirman Soeyitno. 1995. Tinjauan Secara Komprehensif Pengelolaan Hutan Alam Produksi Lestari Hal.42. Proceedings Lokakarya Pembangunan Timber Estates 29-31 Maret di Fakultas Kehutanan IPB Darmaga Bogor

Sumantera, I. W. dan I. N. Peneng, 2005. Pemberdayaan Hutan bamboo sebagai penunjang sosial ekonomi masyarakat Desa Pakraman Angseri, tabanan, Bali. Prosiding Perkembangan Bambu Indonesia. Jogya

Supratman., dan Sahide Muhammad Alif.k. 2013. Hutan Desa dan Pembangunan Social Ekonomi Masyarakat Desa di Kabupaten Bantaeng. Sulawesi Selatan. 
Direktorat Bina Perhutanan Sosial. Jakarta

Suwarno. 2011. PHBM : Alternatif Sistem Pengelolaan Hutan Indonesia. (Online),(http://121.52.132.148/berita.php ?pil=4\&jd $=$ PHBM\%3A+Alternatif + Sistem + Pengelolaan + Hutan + Indonesia $\& d n=200$

71024061450), diakses pada tanggal 10 Desember 2014 